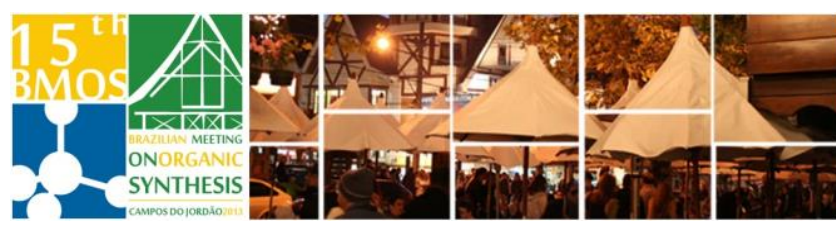

\title{
Synthesis of novel amides derived from lumisantonin
}

\author{
Fernanda C. Moraes, Elson S. Alvarenga, Kariny B. Amorim \\ Federal University of Viçosa, Chemistry Department, Viçosa, Minas Gerais, Brasil 36570-000 \\ *e-mail corresponding author: fernanda.conceicao@ufv.com
}

Keywords: Iumisantonin, amides, sesquiterpene lactones

\section{INTRODUCTION}

Sesquiterpene lactones are present in many medicinal natural sources and exhibit a variety of biological activities ${ }^{1}$. As part of our current synthetic programme related to natural sesquiterpenes with biological activity, we have synthesized a series of (2S)-N-alkyl-2-((3aR,3bS,6S,7S)-7-hydroxy-3a,3bdimethyl-3-oxo-3a,3b,4,5,6,7-hexahydro-3H-cyclo penta[1,3]cyclopropa[1,2]benzen-6-yl)propanamide from lumisantonin which was prepared from the widely available $\alpha$-santonin.

\section{RESULTS AND DISCUSSION}

Irradiation of $\alpha$-santonin in acetonitrile in a quartzo reactor by four low pressure mercury lamps afforded lumisantonin (2) in $91 \%$ yield as a white solid.<smiles>CC1=C2[C@H]3OC(=O)[C@H](C)[C@H]3CC[C@]2(C)C=CC1=O</smiles>

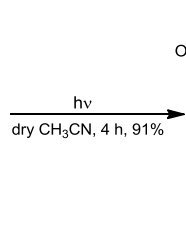

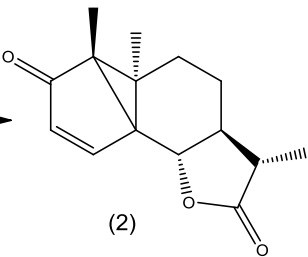

Scheme 1. Synthesis of lumisantonin (2) from a-santonin (1).

The mechanism for the formation of lumisantonin from a-santonin is shown in scheme 2 . The stereochemistry of compound (2) was determined by $\mathrm{x}$-ray data ${ }^{3}$.
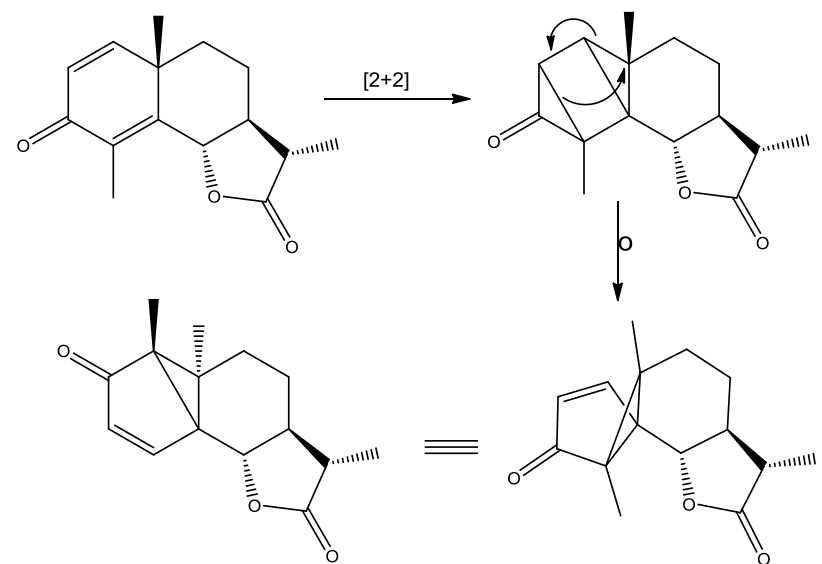

Scheme 2. Mechanism for the formation of lumisantonin from a-santonin.

Ring-opening aminolysis of lumisantonin (2) by the amines displayed in table 1 afforded the novel $15^{\text {th }}$ Brazilian Meeting on Organic Synthesis $-15^{\text {th }}$ BM amides (3-12) in yields varying from 33 to $87 \%$. The amides were obtained by stirring lumisantonin dissolved in dichloromethane in the presence of the corresponding amine.

Table 1. Amines employed in the synthesis of amides (312) from lumisantonin (2) and reaction yields.

\begin{tabular}{|l|l|}
\hline $\mathrm{CH}_{3} \mathrm{NH}_{2}(\mathbf{3}, 33 \%)$ & $\mathrm{CH}_{3} \mathrm{CH}_{2} \mathrm{NH}_{2}(\mathbf{8}, 78 \%)$ \\
\hline $\mathrm{CH}_{3}\left[\mathrm{CH}_{2}\right]_{2} \mathrm{NH}_{2}(\mathbf{4}, 87 \%)$ & $\mathrm{CH}_{3}\left[\mathrm{CH}_{2}\right]_{3} \mathrm{NH}_{2}(\mathbf{9}, 67 \%)$ \\
\hline $\mathrm{CH}_{3}\left[\mathrm{CH}_{2}\right]_{4} \mathrm{NH}_{2}(\mathbf{5}, 74 \%)$ & $\mathrm{CH}_{3}\left[\mathrm{CH}_{2}\right]_{5} \mathrm{NH}_{2}(\mathbf{1 0}, 60 \%)$ \\
\hline$\left(\mathrm{CH}_{3}\right)_{2} \mathrm{CHCH}_{2} \mathrm{NH}_{2}(\mathbf{6}, 61 \%)$ & $\left(\mathrm{CH}_{3}\right)_{2} \mathrm{CHNH}_{2}(\mathbf{1 1}, 62 \%)$ \\
\hline$\prod_{(\mathbf{N}}^{\mathrm{H}}$ & \\
\hline
\end{tabular}

All compounds synthesized were characterized by infrared, ${ }^{1} \mathrm{H}$ and ${ }^{13} \mathrm{C}$ NMR, HETCOR/COSY and mass spectrometry.

\section{CONCLUSION}

The aminolysis reaction was carried out without any special conditions, catalyst and harsh conditions. Ten novel amides derived from lumisantonin were prepared and their phytotoxic potential is under evaluation.

\section{ACKNOWLEDGEMENTS}

We would like to thank UFV, CAPES, CNPq and FAPEMIG for financial support.

\section{REFERENCES}

${ }^{1}$ Macías, A. F.; Fernandes S A.; Varela, R. M.; Molinillo, J. M. G.; Torres, A.; Alves, P. L. C. A. J. Nat. Prod., v.69, p. 795-800, 2006.

${ }^{2}$ Hu, D; Wan, Q; Yang, S; Bhadury, P, S; Jin, L; Yan, K; Liu, F; Chen, Z; Xue, W. J. Agric. Food Chem. v. 56, 998-1001, 2008.

${ }^{3}$ Barton, D. H. R.; Miki, T.; Pinhey, J. T.; Wells, R. J.; Proc. Chem. Soc. 1962, 112 